УДК 656.13:656.08

DOI: https://doi.org/10.26642/ten-2021-1(87)-28-37

\author{
В.П. Мурашковська, ст. викладач \\ Я.В. Кужельний, к.т.н. \\ В.М. Скляр, аспірант \\ О.С. Слсднікова, к.т.н. \\ Національний університет «Чернігівська політехніка»
}

\title{
Аналіз впливу технічного стану автомобіля на рівень аварійності на дорогах
}

Однією з провідних галузей економіки багатьох країн є транспортна галузь. У сучасному світі автомобільний транспорт вважається одним із двигунів прогресу. Середній вік парку автомобілів Євросоюзу становить 8 років, США - 11 років, Украйни - 22,4 роки. На сьогоднішній день в Україні склалася така невтішна економічна ситуація, коли вигідніше придбати автомобіль з пробігом, зокрема легковий, ніж новий із автосалону. Зазвичай, иі автомобілі мають знижені показники технічного стану та експлуатаційні характеристики. Також на изі параметри негативно впливають несвоєчасні регламентований технічний огляд, заміна витратних матеріалів, ремонт автомобіля, якими досить часто зловживають водії та власники автомобілів. Це все впливає на активну безпеку та рівень аварійності на дорогах.

У статті розглянуто аналіз впливу технічного стану автомобіля на рівень аварійності на дорогах. Наведено показники смертності від дорожньо-транспортних пригод деяких країн світу, смертність в Свропейському Союзі від дорожньо-транспортних пригод за віковими категоріями, кількість дорожньо-транспортних пригод в Украӥні за 2017-2020 роки, ефективність функиіонування системи «водій - автомобіль - дорога - середовище» щзодо попередження дорожньо-транспортних пригод $i$ забезпечення безпеки дорожнього руху, швидкісні обмеження по тяжкості наслідків дорожньо-транспортних пригод, вплив швидкості на ймовірність отримання смертельних травм при наїзді транспортного засобу на пішохода, довжину гальмівного иляху при екстреному гальмуванні, динаміку насичення Свропейського парку транспортними засобами з максимальною швидкістю руху більше 150 км/год, інфографіку автопарку України. Проаналізовано вплив технічного стану рульового керування, елементів підвіски та гальмівної системи на керованість і стійкість автомобілів.

Ключові слова: автомобільний транспорт; технічний стан автомобілів; експлуатаційні властивості автомобілів; аварійність на дорогах; безпека дорожнього руху.

Актуальність теми. Автомобільний транспорт $є$ важливою складовою економічного розвитку суспільства. Під час кермування автомобільним транспортом, як легковим так і вантажним, при незадовільному технічному стані стається багато дорожньо-транспортних пригод (ДТП), які можуть призвести до погіршення стану здоров'я, загибелі людей, а також фінансових втрат. Вони виникають 3 багатьох причин, серед яких є як людський, так і технічний (відмова вузлів та агрегатів та ін.) фактор.

Разом 3 цим, відсутнє узагальнення аналізу аварійності та особливості їі виникнення залежно від технічного стану автомобіля. Аналіз цих впливів на аварійність $є$ актуальною науково-технічною задачею.

Аналіз останніх досліджень та публікацій, на які спираються автори. Питання технічного стану автомобіля та аварійності на дорогах досліджували Р.І. Михайлов, В.Н. Добромиров, С.С. Євтюков, M.G. Lay, Є.Л. Хаапаніємі, Ю.Торніайнен, Є.Сваткова, Ю.Хювярінєн, М.А. Подригало, Д.В. Абрамов, О.В. Бевз, С.О. Магопець, В.А. Онопа, М.О. Головань, Ю.Ю. Кукурудзняк та інші.

Щорічна статистика ДТП та їх основних видів і причин у всьому світі ведеться різними міжнародними базами, що дає можливість оцінити стан безпеки дорожнього руху на автомобільному транспорті [1, 2].

У роботі М.О. Голованя [3] було розглянуто безпеку транспортного засобу під час його експлуатації та після ремонту. Для зменшення кількості ДТП необхідно забезпечити достатній рівень технічної безпеки автомобілів. При експлуатації автомобілів з'являються несправності і відбувається старіння транспортних засобів (Т3), зниження надійності систем контролю і управління безпекою.

У роботі Ю.Ю. Кукурудзняка [4] проведено моніторинг технічного стану автомобіля за різних умов експлуатації. Діюча планово-попереджувальна система технічного огляду (ТО) і ремонту автомобілів передбачає обов'язкове періодичне виконання регламентних профілактичних робіт та виконання відновлювальних робіт за потребою. Виконання робіт «за станом» потребує постійного потоку інформації про поточний технічний стан автомобіля. 
У роботі [5] проведено порівняння середнього віку автомобілів деяких країн, а саме: в Саудівській Аварії - 3 роки, в країнах Свросоюзу - 8 років, в США - 11 років, в Росії - 12. Гірше, ніж в Україні, справи йдуть на Кубі - там середній вік машин становить 38 років.

Однак розглянуті нами наукові роботи не дозволяють сукупно оцінювати вплив технічного стану автомобіля та його експлуатаційних характеристик на рівень аварійності на дорогах.

Метою статті є аналіз впливу технічного стану автомобіля та його експлуатаційних характеристик на рівень аварійності та особливості її виникнення на дорогах.

Викладення основного матеріалу. У 2010 році Генеральна Асамблея Організації Об'єднаних Націй проголосила 2011-2020 роки десятиліттям дій щодо забезпечення безпеки дорожнього руху (БДР) 3 глобальною метою скоротити рівень смертності від травм, отриманих у результаті ДТП. Для вимірювання досягнутого прогресу Всесвітня організація охорони здоров’я (ВООЗ) опублікувала доповідь про стан БДР у світі за 2013 рік [6].

Тематика БДР на сьогоднішній день залишається актуальною в усьому світі. Цій проблемі присвячена велика кількість зарубіжної та вітчизняної літератури [1-9].

ДТП є основною причиною смерті серед молоді віком від 15 до 29 років та другою по значущості причиною смерті серед дітей віком від 5 до 14 років.

На рисунку 1 наведено показники смертності від ДТП в різних країнах світу. Із вказаних даних видно, що значне зростання смертності на дорогах спостерігається більше ніж у половині з розглянутих держав. Це свідчить про те, що навіть в низці країн світу з високим рівнем розвитку економіки $\mathrm{i}$ соціальної захищеності громадян ДТП залишаються проблемою.

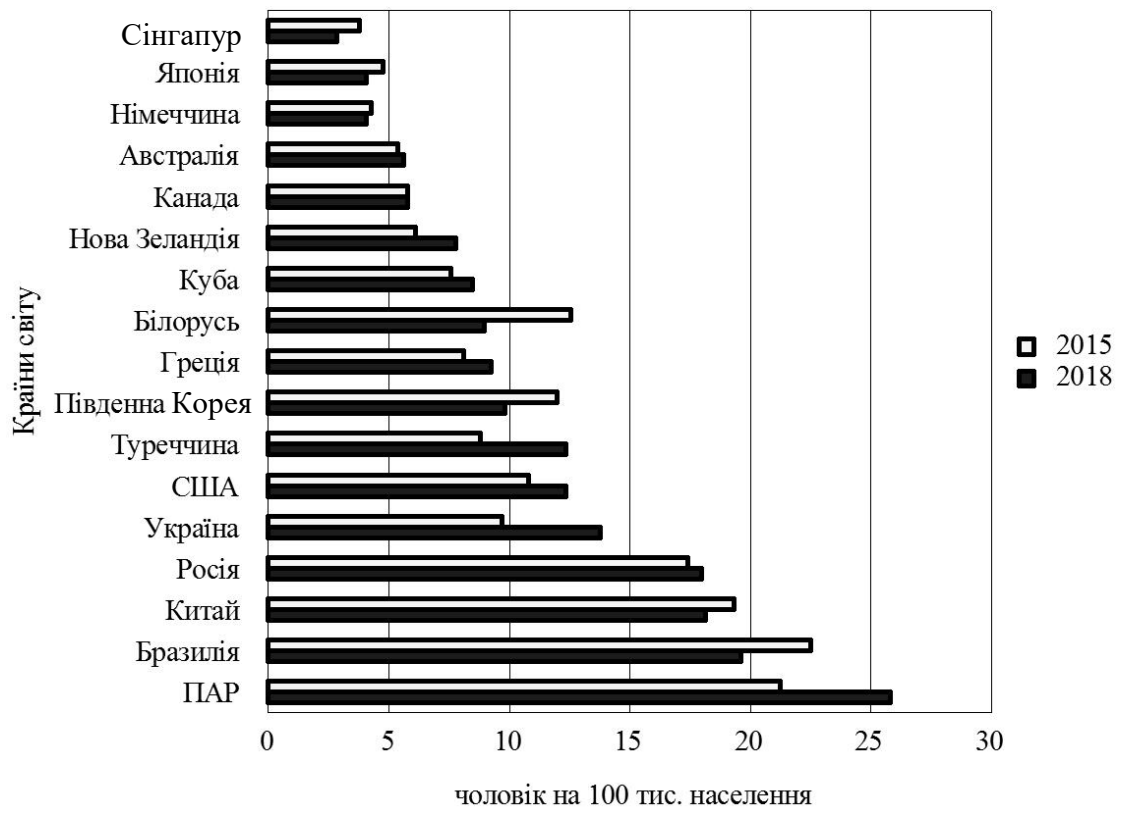

Рис. 1. Показники смертності від ДТП в деяких краӥнах світу [8]

Глави держав, які зібралися на Генеральній Асамблеї ООН, затвердили історичні цілі в галузі сталого розвитку. Дві з цих цілей пов'язані із забезпеченням безпеки дорожнього руху:

1) дворазове скорочення кількості смертей і травм у результаті ДТП в усьому світі до 2020 року;

2) до 2030 року забезпечити широке впровадження безпечних і стійких транспортних систем. Однак iз сучасного стану справ можна сказати, що в зазначені терміни досягнення цих цілей проблематичне [6].

Прикладом успішної боротьби зі смертністю на дорогах $\epsilon$ європейський регіон, оскільки має найнижчий показник дорожньо-транспортної смертності в світі. Показник смертності від травм, отриманих в ДТП, в країнах Свропи (рис. 2) в 1,8 раза нижче, ніж середньосвітовий (9,3 загиблих на 100000 населення порівняно з 17,4 на 100000 населення в світі), і нижче, ніж в інших регіонах ВООЗ. 


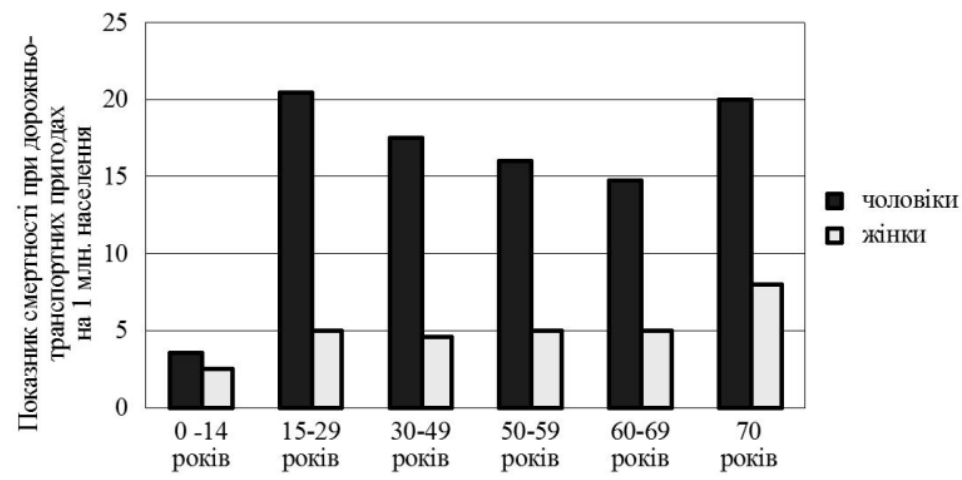

Рис. 2. Смертність в Свропейському Союзі від ДТП за віковими групами населення [8]

Статистика смертності не повністю відображає масштаби збитку, що наноситься дорожніми аваріями. Дуже обмежена кількість інформації систематично збирається про тяжкість отриманих травм, у результаті яких виникає інвалідність, та їх руйнівний вплив на людські долі. Ці травми є тягарем, що накладається ними на систему охорони здоров'я, і витрати, які несе суспільство в цілому. Так у 2018 році країни Європейського Союзу повідомили про 1,65 млн несмертельних травм. Це дозволяє припустити, що на кожного загиблого в ДТП припадає в середньому 23 постраждалих.

Забезпечення безпеки дорожнього руху має за мету попередження, запобігання та усунення явищ i небезпечних ситуацій, що загрожують життю і здоров'ю людей, майну громадян, підприємств, установ і організацій, і їх наслідків. Інтереси безпеки дорожнього руху будь-яких видів транспортних перевезень, охорона життя, здоров’я та майна громадян, захист їх прав, законних інтересів і майна - це основні пріоритети організації дорожнього руху (ДР) і в Україні, і в зарубіжних країнах.

Саме 3 цією метою встановлюються дозвільні режими в сфері безпеки дорожнього руху для попередження транспортних пригод, зниження тяжкості їх наслідків. Тому безпеку дорожнього руху (ДР) слід розглядати з конституційно-правової точки зору як одну з гарантій конституційного права на життя. Аварійність на автомобільному транспорті завдає величезних матеріальних і моральних збитків як суспільству в цілому, так і окремим громадянам.

На рисунку 3 показано загальну кількість ДТП на території України та кількість постраждалих та/або загиблих у ДТП за 2017-2020 роки.

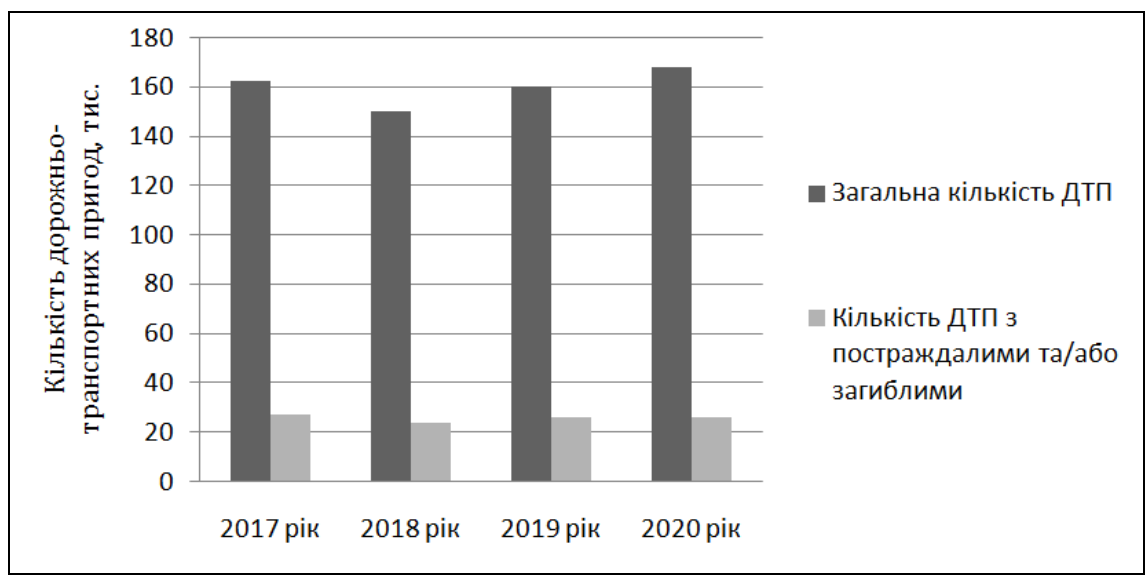

Рис. 3. Кількість ДТП в Україні за 2017-2020 роки [9]

Особливостями сучасної української дійсності, що ускладнюють боротьбу з аварійністю і формують тенденції до погіршення ситуації, $є$ :

- безперервно зростаючі вимоги суспільства до підвищення мобільності населення, які супроводжуються інтенсивним зростанням парку автотранспортних засобів (АТЗ);

- збереження незначної ролі громадського транспорту в забезпеченні перевезень населення і значний обсяг перевезень особистим транспортом;

- істотний перерозподіл обсягів вантажоперевезень між залізничним та автомобільним транспортом на користь останнього;

- низька якість стану, облаштування та утримання дорожньої мережі; 
- диспропорція між збільшенням кількості автомобілів, протяжністю і пропускною спроможністю відрізка дорожньої мережі країни, яка не розрахована на сучасні транспортні потоки: в даний час рівень забезпечення автомобілями в містах становить 200 штук на 1 тис. жителів, тоді як дорожньо-транспортна інфраструктура відповідає рівню 60-100 штук на 1 тис. жителів;

- низька дисципліна учасників дорожнього руху, яка провокується недосконалістю нормативноправової бази в сфері забезпечення безпеки дорожнього руху і негативним менталітетом значної групи водіїв, яка сформувалася в роки «дорожнього свавілля».

Згідно з правилами дорожнього руху (ПДР), учасниками дорожнього руху є водії, пішоходи та пасажири. При цьому кількість дорожньо-транспортних пригод через порушення ПДР водіями транспортних засобів, що спричинили шкоду здоров'ю та/або загибель у середньому за рік, за останні п'ять років становить $85 \%$ від усіх учасників ДТП, а через порушення правил дорожнього руху пішоходами $-13 \%$.

Згідно з даними основними причинами аварійності на дорогах є: виїзд на смугу зустрічного руху 14,8 \%, невідповідність швидкості конкретним умовам руху або їі перевищення - 9,9 \% і порушення правил розташування транспортних засобів на проїзній частині - 9,6\%.

Сьогодні, в умовах безперервного насичення світового парку АТЗ високошвидкісними автомобілями, неминуче виникає питання про введення розумних швидкісних обмежень на автодорогах і міських вулицях. Встановлення таких обмежень неможливе без аналізу факторів, що визначають ефективність функціонування системи «водій - автомобіль - дорога - середовище» (ВАДС) щодо попередження ДТП і забезпечення безпеки дорожнього руху. Основними 3 цих факторів є: людський фактор; технічний фактор; дорожній фактор і фактор дорожньої середовища.

Кожен із чинників визначається низкою показників, що мають цілком певні кількісні або якісні межі (рис. 4). Нижче наведено аналіз впливу основних показників перерахованих факторів на формування передумов до ДТП внаслідок неправильного вибору швидкості.

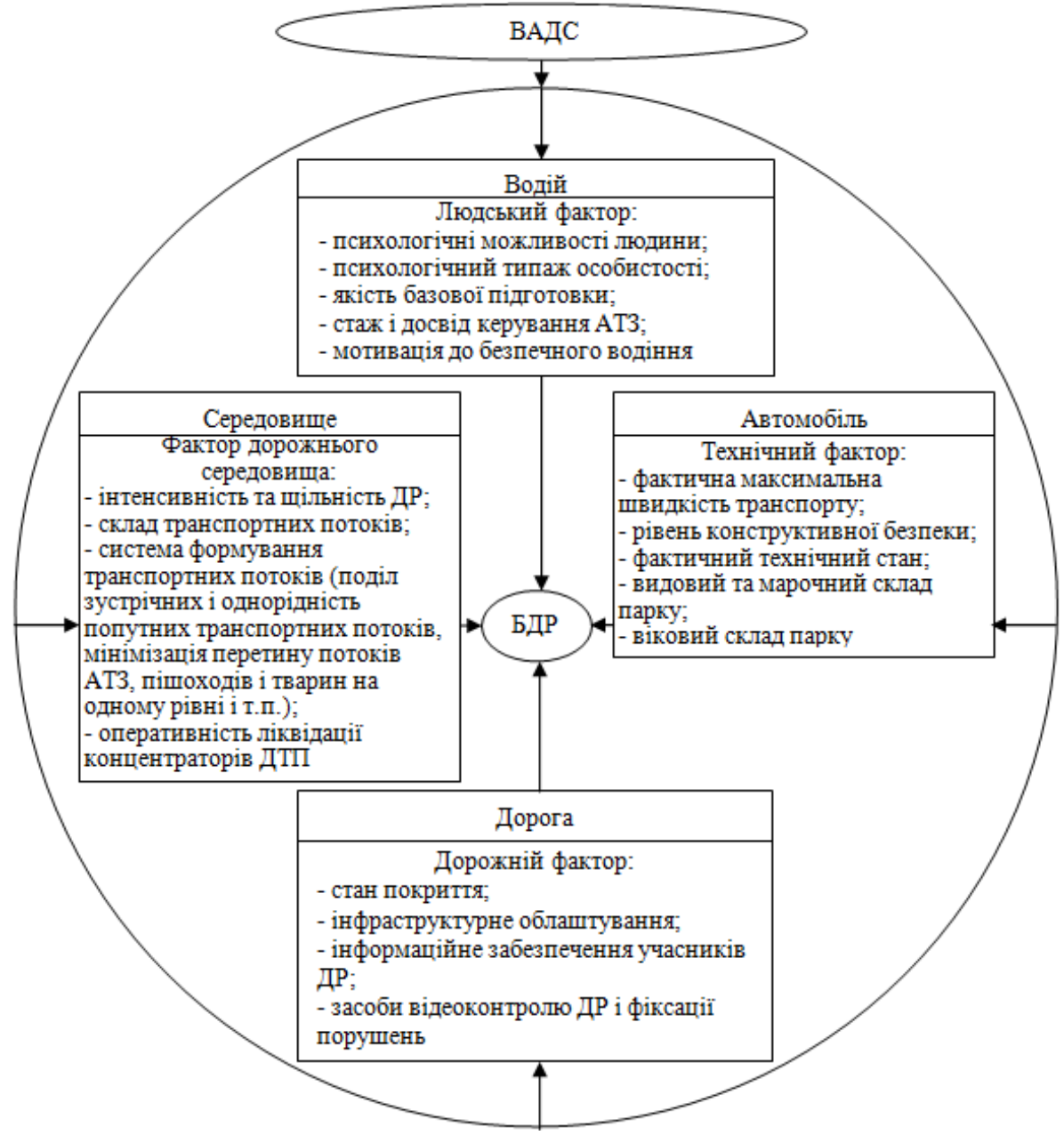

Рис. 4. Система ВАДС в застосуванні до забезпечення безпеки дорожнього руху на основі регулювання швидкісних режимів руху [8] 
Головним фізіологічним обмеженням при цьому $є$ фізична можливість людського організму по сприйняттю імпульсу енергії від зіткнення без летального результату і особливо важких травм. Аналіз даних, наведених в роботах [11-13], показує, що швидкісні обмеження, що діють в Україні і в деяких країнах за кордоном для міських дорожніх мереж, з урахуванням застосування обмежувачів руху в зонах пішохідних переходів, в основному відповідають максимальним швидкостям, розрахованим 3 позиції порогового значення появи при ДТП ризику смертельних травм для водія, пасажирів Т3 (табл. 1) i пішоходів (рис. 5).

Швидкісні обмеження по тяжкості наслідків ДТП [10]

\begin{tabular}{|c|c|c|}
\hline Вид зіткнення & Елементи конструктивної безпеки АТЗ & $\begin{array}{c}\text { Поріг ризику } \\
\text { смертельних травм }\end{array}$ \\
\cline { 1 - 2 } Фронтальний удар & Ремені і подушки безпеки, енергопоглинаючі & 70 км/год \\
\cline { 1 - 1 } Бічний удар & елементи в конструкції & 50 км/год \\
\hline Наїзд на пішохода & - & 30 км/год \\
\hline
\end{tabular}

При регламентуванні швидкості на заміських автошляхах необхідно врахувати, що швидкісні обмеження в 90 км/год практично не залишають шансів для виживання учасникам ДТП при зіткненні без гальмування (наприклад, бічний удар в автомобіль, який несподівано з'явився 3 дороги, що примикає).

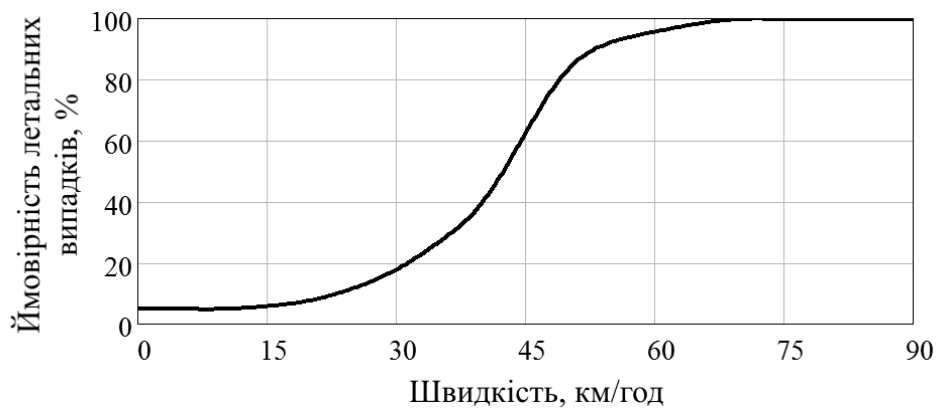

Рис. 5. Вплив швидкості на ймовірність отримання смертельних травм при наӥзді транспортного засобу на пішохода [10]

Крім того, зниження швидкості до моменту удару при ДТП займає певний час і значна частина кінетичної енергії Т3 може в момент зіткнення виявитися непогашеною гальмівними механізмами.

Ймовірність виникнення подібної ситуації на підвищених швидкостях зростає внаслідок збільшення відстані, яку проходить ТЗ за час реакції водія, при одночасному збільшенні довжини гальмівного шляху. На рисунку 6 вказано шляхи, які проходять Т3 при екстреному гальмуванні, 3 різними початковими швидкостями при допущенні, що час реакції водія в межах 1 секунди.

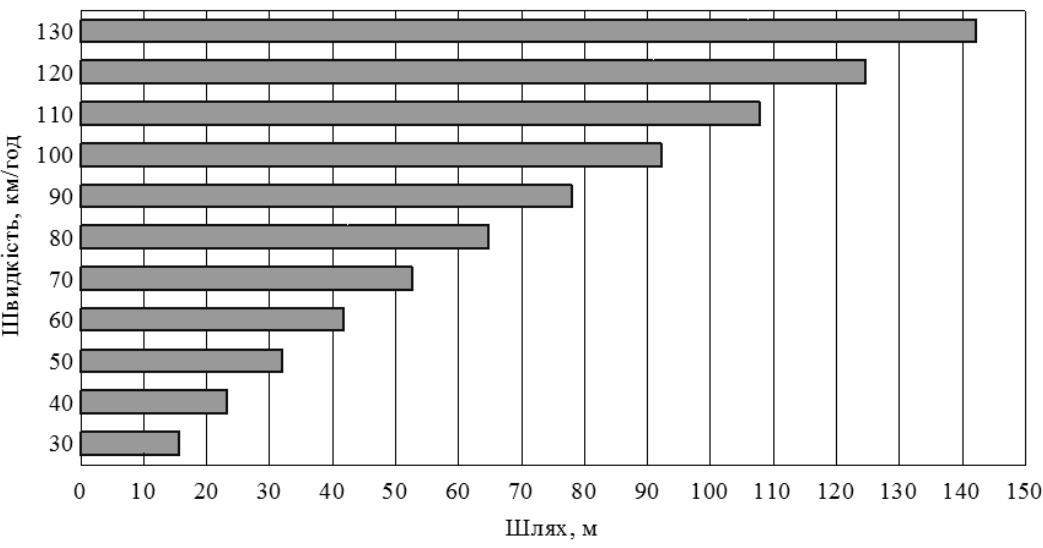

Рис. 6. Довжина гальмівного шляху при екстреному гальмуванні [10] 
Наведені результати розрахунків свідчать про те, що повне погашення кінетичної енергії автомобіля, що рухається в автомобільному потоці помірної щільності зі швидкістю понад 80 км/год, навіть за мінімального часу реакції водія є проблематичним, не кажучи вже про ситуації, коли цей час може зростати через психологічний стан і вік водія до 3 секунд.

Важливим психологічним показником є здатність водія правильно оцінювати швидкість руху і часові інтервали. Дослідження [15] показали, що в загальному транспортному потоці не менше за 15 \% водіїв рухаються зі швидкістю, що перевищує швидкість транспортного потоку, а до $40 \%$ - припускаються помилки в бік заниження швидкості свого автомобіля.

Відомо, що найбільш безпечною є швидкість, яка дорівнює швидкості транспортного потоку. При відхиленні швидкості руху транспортних засобів у потоці від швидкості потоку на 30 км/год в більшу або меншу сторону ймовірність виникнення ДТП зростає в 10 разів. Реальні ж відмінності в швидкостях руху, наприклад на автомагістралях, у зв'язку з різними технічними можливостями ТЗ можуть досягати 60 км/год, а це ще неодноразово збільшує ймовірність ДТП.

Розглядаючи вплив психологічного аспекту на безпеку дорожнього руху, необхідно зазначити, що в реальних дорожніх ситуаціях часто виникають моменти, які провокують навіть дисциплінованих водіїв на незначне перевищення швидкості. Всупереч існуючій думці, що невелике перевищення швидкості не впливає на БДР, дослідження показують, що перевищення швидкісного обмеження в межах міста на 5 км/год, а на заміській дорозі на 10 км/год підвищує ризик виникнення ДТП в 2 рази.

Основними показниками впливу на БДР технічного чинника 3 позиції швидкості $є$ фактична максимальна швидкість і ступінь конструктивної досконалості Т3, їх фактичний технічний стан, а також склад і вікова структура парку. Сучасний світовий автомобільний парк характеризується значною неоднорідністю конструктивної досконалості і технічного стану автомобілів. Статистичний аналіз показує, що за рівнем фактичної максимальної швидкості вже з 2006 року автомобільний парк Європи практично на 100 \% поповнюється автомобілями, здатними рухатися зі швидкістю 150 км/год і більше (рис. 7).

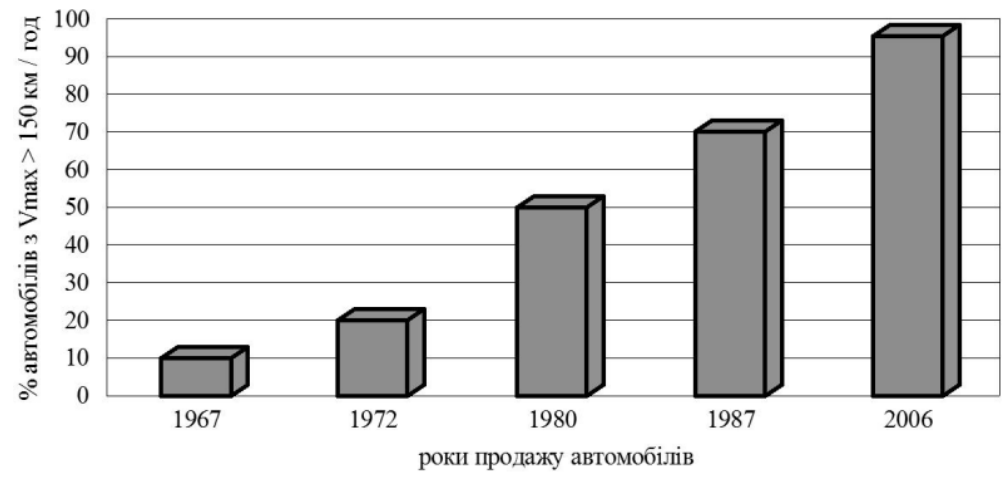

\section{Рис. 7. Динаміка насичення європейського парку Т3 з Vmax > 150 км/год [10]}

При цьому за даними Свропейської ради з безпеки транспорту гіпотетичне одномоментне оновлення в такій ситуації всього, що нині експлуатується в парку Т3, до рівня найбезпечнішого в своєму класі автомобіля здатне знизити смертність на дорогах Свропи на 40...50 \%. Ці цифри наводять на думку про те, що істотне зростання потенційної небезпеки сучасного парку автомобілів за рахунок насичення його високошвидкісними зразками посилюється наявністю в ньому значної частки вікових машин (до 40...50 \%), не повною мірою відповідають сучасними вимогами щодо їх конструктивної безпеки.

Аналіз вікового складу українського автомобільного парку показує, що вказане вище співвідношення автомобілів з різними рівнями конструктивної безпеки також наявне. Федерація роботодавців автомобільної галузі України оприлюднила інфографіку (рис. 8), в якій зібрано декілька цікавих фактів про автопарк нашої країни станом на 2019 рік. Відповідно до неї, загальна кількість зареєстрованих в Україні транспортних засобів на кінець 2019 року становить 9,7 млн одиниць (в минулому було 9,2 млн). 3 них легкові автомобілі - 8,4 млн (було 7,9 млн) [15].

Таким чином, рівень автомобілізації в нашій країні досягає 232 автомобіля на 1000 жителів.

Середній вік парку легкових автомобілів становить 22,4 роки - це на 0,4 більше ніж в попередньому році. Так сталося не тільки через старіння внутрішнього автопарку, а й через ввезення в Україну переважно старих автомобілів - частка імпорту легкових Т3 старше 8 років становить 56 \% (ще рік тому цей показник був на рівні 7 \%). 


\section{Три факти про автопарк України}

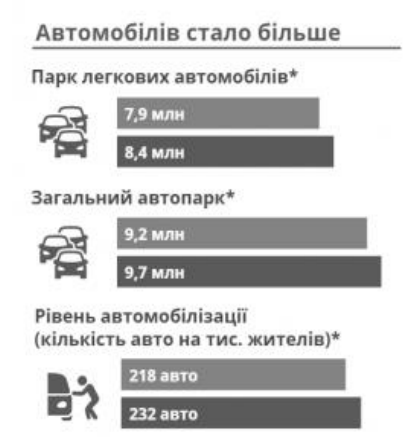

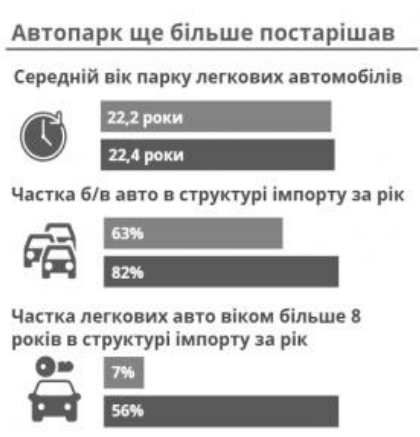

Парк електромобілів

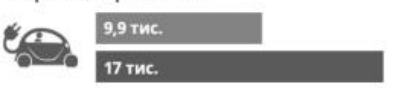

Парк гібридів

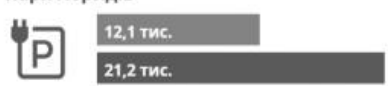

Рис. 8. Інфографіка автопарку Украӥни [16]

3 огляду на те, що початок інтенсивного оснащення АТЗ сучасними системами конструктивної безпеки приходиться на 1990-ті роки і, орієнтуючись на зазначену вікову структуру автомобільного парку, можна припустити, що сучасним вимогам конструктивної безпеки в ньому відповідає не більше 50 \% легкових автомобілів, 30 \% автобусів і 22 \% вантажівок. А це означає, що по дорогах України сьогодні може пересуватися в цілому до 24 млн одиниць АТЗ, які не повною мірою відповідають сучасним вимогам безпеки конструкції.

Вибір безпечної швидкості визначається станом дорожнього покриття, якістю інфраструктурного облаштування вулично-дорожньої мережі, рівнем досконалості управління дорожнім рухом.

Останнє значною мірою забезпечує створення сприятливого дорожнього середовища: формування однорідних транспортних потоків по смугах руху, нормування їх безпечного швидкісного режиму, раціональне використання реверсивних смуг, безконфліктне світлофорне регулюванню на перехрестях тощо. На жаль, усі ці перераховані показники факторів дороги і дорожнього середовища в українській дійсності могли б бути кращими. Така дорожня ситуація в сукупності з автомобільним парком значною мірою не відповідає вимогам забезпечення конструктивної безпеки машин, генерує схильність дорожньо-транспортної системи України до ДТП.

Всесвітня організація охорони здоров'я вказує найважливішу роль для забезпечення БДР в подібних ситуаціях - це управління швидкістю. Мета управління - визначити рівень швидкості, необхідний для безпечного пересування ТЗ вулицями або дорогами, та вжити заходів для досягнення цієї мети.

Найважливішим елементом управління швидкістю, на думку ВООЗ, є обгрунтований вибір обмеження швидкості, зрозумілий i роз'яснений населенню. При цьому необхідний контроль швидкісного режиму і застосування невідворотних санкцій до порушників. За аналізом ВООЗ невиконання останньої умови не забезпечує необхідних результатів з управління швидкістю.

Розвиток конструкцій автомобілів супроводжується ростом показників їх динамічних властивостей. Динамічні властивості визначають здатність автомобіля вписуватися в завантажений міський транспортний потік. Одним із показників динамічних властивостей є прискорення автомобіля, що розвивається при рушанні з місця або при розгоні з певної швидкості [17].

Керованість і стійкість - це здатність автомобіля змінювати траєкторію руху при впливі водія на кермове колесо, а також зберігати напрямок руху і орієнтацію поздовжньої і вертикальної осей незалежно від дії зовнішніх та інерційних сил.

На керованість і стійкість автомобіля впливає велика кількість чинників. Основні з них:

- керовані (залежні від технічного стану автомобіля) організаційно-технологічні чинники;

- частково керовані фактори - кваліфікація водія, якість елементів автомобіля;

- некеровані фактори (які не залежать від технічного стану автомобіля) - експлуатаційні фактори, дорожньо-кліматичні умови, конструкція автомобіля.

Експлуатаційні властивості автомобіля залежать від експлуатаційних факторів (інтенсивності експлуатації, швидкісного режиму і кваліфікації водія) [18].

Від керованості і стійкості автомобіля залежить активна безпека, яка є однією з головних складових експлуатаційних властивостей транспортного засобу.

На експлуатаційні властивості автомобіля суттєво впливають конструктивні особливості й технічний стан рульового керування, елементів підвіски та гальмівної системи. Також до факторів, що впливають на експлуатаційні властивості автомобіля, слід зарахувати зміну технічного стану та жорсткості несучої 
системи в процесі експлуатації. Пі час експлуатації автомобіля відбувається зміна технічного стану кузова (ушкодження при дорожньо-транспортних пригодах, втомлювальне руйнування елементів кузова, корозія, порушення умов експлуатації автомобіля), що призводить до зміни розмірів перерізів і зазорів між деталями кузова, які з’єднуються, а також зміщення контрольних точок основи кузова відносно їх номінального положення [19].

Від характеристик та технічного стану гальмівної системи автомобілів значною мірою залежить безпека руху. Автомобіль при русі має кінетичну енергію. При гальмуванні кінетична енергія руху перетворюється в теплову енергію, при цьому відбувається нагрівання гальм, в першу чергу гальмівних дисків, які нагріваються нерівномірно. Це зумовлює зміну геометричної форми диска та його товщини. Плоскі робочі поверхні диска деформуються, характер їх зносу стає нерівномірним, найвища величина зносу досягається в зоні максимального нагріву. Різні абразивні частинки, які потрапляють між диск і гальмівні колодки, прискорюють процес зносу. При цьому площа контакту між диском і колодкою зменшується, що потребує збільшення сили натиску водієм на педаль гальмування, може виникнути ситуація, коли сила тиску, що розвивається гальмівним циліндром, буде недостатньою для забезпечення надійного й ефективного гальмування. Гальмівний шлях, за значної зміни геометричної форми диска, стає неприпустимо більшим, особливо на слизькій дорозі [20].

Збільшення експлуатаційних відмов відбувається внаслідок неправильної експлуатації автомобіля або його елементів, порушення режимів технічного обслуговування та інших факторів. Майже половина всіх відмов належить до поступових, з яких 60-65 \% залежать від регулярності та якості виконання операцій технічного обслуговування. Біля $20 \%$ становить кількість раптових відмов, появу яких неможливо спрогнозувати за результатами статистичного аналізу.

Для того щоб поліпшити експлуатаційні властивості автомобілів і підвищити техніко-економічні показники (безпека руху, продуктивність, економічність, рентабельність), необхідно знати закономірності зміни їх технічного стану, причини і характер виникнення відмов [21].

У рульовому керуванні автомобіля зносу піддаються деталі та спряження як механізму так і приводу. У механізмі зношуються поверхні деталей зачеплення черв'як-ролик. Вони піддаються окислювальному та корозійно-абразивному виду зношення.

Зношення деталей рульового механізму i його приводу призводить до погіршення такої експлуатаційної властивості автомобіля, як керованість. Це погіршення проявляється у збільшенні вільного ходу кермового колеса, з'являється люфт у з'єднаннях механізмів, розрегулюванні сходження керованих коліс, також відбуваються експлуатаційні руйнування поворотних кулаків, зносі підшипників та гнізд під зовнішні обойми в маточинах коліс.

У незалежних підвісах автомобілів, зазвичай, зношуються робочі поверхні пальців та втулок важелів, шарові опори. Окрім абразивного зносу шарові опори також піддаються втомному руйнуванню, що призводить до раптової втрати працездатності автомобіля, а відповідно й до виникнення аварійних ситуацій. Втомному зносу та руйнуванню піддаються також пружинні елементи та листові ресори.

У залежних підвісках, окрім пальців, зношуються та руйнуються ресорні листи.

До втрати працездатності гальмівного механізму призводить підвищена температура нагрівання накладок. Підвищення температури може спричинити екстрене гальмування та недостатнє тепловідведення від деталей гальмівного механізму. Ступінь зносу гальмівних накладок зумовлює збільшення зазорів між робочими поверхнями, а це є однією з причин втрати працездатності гальмівного механізму або погіршення експлуатаційних властивостей автомобіля - зростання гальмівного шляху та часу гальмування.

Висновки та перспективи подальших досліджень. На основі аналізу розглянутих джерел та власних досліджень технічного стану автомобілів встановлено, що підвищення технічного стану автомобіля та його експлуатаційних характеристик забезпечить підвищення надійності та керованості автомобіля та мінімізує аварійність на дорогах.

Необхідний рівень безпеки на автомобільному транспорті формується не лише дорожньою інфраструктурою, а й технічним станом систем і вузлів автомобіля: рульового керування, гальмівної системи, елементів підвіски та ін. Тому своєчасна діагностика та ремонт цих систем і вузлів забезпечує необхідний рівень безпеки руху й зменшує ймовірність створення аварійних ситуацій на дорогах.

Доцільно продовжити дослідження технічного стану автомобілів вітчизняного й зарубіжного виробництва $з$ різним пробігом й різним терміном експлуатації і його впливу на ймовірність виникнення ДТП.

\section{Список використаної літератури:}

1. Mobility and transport road safety / An official website of the European Union [Electronic resource]. - Access mode : https://ec.europa.eu/transport/road_safety/specialist/statistics_en.

2. Road Safety / National Highway Traffic Safety Administration (NHTSA) [Electronic resource]. - Access mode : https://www.nhtsa.gov/road-safety. 
3. Головань М.О. Реалізація ресурсу і безпеки транспортних засобів на стадіях виготовлення, експлуатації та після ремонту / М.О. Головань // Новітні технології. - 2012. - № 4 (38). - С. 85-92.

4. Кукурудзяк Ю.Ю. Моніторинг технічного стану автомобіля при різних умовах експлуатації / Ю.Ю. Кукурудзяк // Наукові нотатки. - 2016. - № 55. - С. 228-231.

5. Средний возраст автомобилей в Украине превышает 20 лет. ТСН [Электронный ресурс]. - Режим доступа : https://tsn.ua/ru/ukrayina/sredniy-vozrast-avtomobiley-v-ukraine-prevyshaet-20-let-1146537.html.

6. Резолюция, принятая Генеральной Ассамблеей 25 сентября 2015 года / Организация Объединенных Наций. Генеральная Ассамблея. - 2015. - 44 с. [Электронный ресурс]. - Режим доступа : https://unctad.org/meetings/en/SessionalDocuments/ares70d1_ru.pdf.

7. Михайлов P.I. Сучасні підходи забезпечення безпеки дорожнього руху в Україні: шляхи та досвід удосконалення / P.I. Михайлов // Держава та регіони. - 2010. - № 2. - С. 156-161.

8. Евтюков С.С. Методология оценки и повышения эффективности дорожно-транспортных экспертиз : дис. ... д.т.н. ; 05.22.10 / С.С. Евтюков. - СПб., 2020. - 355 с.

9. Статистика. Патрульна поліція [Електронний ресурс]. - Режим доступу : http://patrol.police.gov.ua/statystyka/.

10. Добромиров В.Н. Скорость как фактор влияния на безопасность дорожного движения. / В.Н. Добромиров, С.С. Евтюков // Современные проблемы науки и образования. - 2013. - № 5 [Электронный ресурс]. Режим доступа : https://www.science-education.ru/ru/article/view?id=10248.

11. Европейский доклад о состоянии безопасности дорожного движения «За безопасные дороги и более здоровые транспортные альтернативы» / Всемирная организация здравоохранения. - 2009. - 161 с. [Электронный ресурс]. - Режим доступа : https://www.science-education.ru/ru/article/view?id=10248.

12. Lay M.G. Ways of the World: A History of the World's Roads and of the Vehicles That Used Them / M.G. Lay // New Brunswick : Rutgers University Press, 1992. - 401 p.

13. World report on road traffic injury prevention / World Health Organization. - Geneva, 2004. - 217 p. [Electronic resource]. Access mode : https://apps. who.int/iris/bitstream/handle/10665/42871/9241562609.pdf?sequence=1\&isAllowed=y.

14. The Automobile: A Century of Progress / Warrendale: Society of Automotive Engineer, 1997. - 298 p.

15. Принципы и инструменты для повышения безопасности дорожного движения на дорогах общего пользования / Е.Л. Хаапаниеми, Ю.Торниайнен, Е.Сваткова, Ю.Хювяринен. // Международный опыт: Россия-Финляндия. - 2008 - 270 с. [Электронный ресурс]. - Режим доступа : https://www.ador.ru/data/files/static/bdd_01.pdf.

16. Три факта об автопарке Украины в 2019 году: инфографика. Auto24 [Электронный ресурс]. - Режим доступа : https://auto.24tv.ua/ru/tri_fakta_ob_avtoparke_ukrainy_v_2019_godu_infografika_n19433.

17. Подригало М.A. Определение предельных динамических показателей легкових автомобилей / М.А. Подригало, Д.В. Абрамов // Механіка та машинобудування : науково-технічний журнал. - Харків : НТУ «ХПІ», 2013. - № 1. - С. 81-91.

18. Крупчан В.О. Аналіз факторів, що впливають на керованість і стійкість автомобіля : матеріали міжнародної студентської конференції «Експлуатація та сервісна інженерія» / В.О. Крупчан. - Харків : ХНТУСГ, 2020. C. $12-13$.

19. Врадій І.О. Дослідження впливу зміни геометричних параметрів несучої системи легкового автомобіля на показники поворотності і стійкості : збірник тез доповідей VIII Всеукраїнської науково-практичної конференції студентів та аспірантів «Підвищення надійності машин і обладнання». Ч. II. / I.O. Bpadiŭ, C.О. Магопеиь. - Кіровоград : КНТУ, 2014. - С. 6-8.

20. Бевз O.B. Дослідження працездатності пари тертя «гальмівний диск - гальмівна колодка» легкового автомобіля / O.B. Бевз, C.O. Магопецьь, В.A. Онопа // Збірник наукових праць Кіровоградського національного технічного університету. Техніка в сільськогосподарському виробництві, галузеве машинобудування, автоматизація. - 2010. - Вип. 23. - С. 23-28.

21. Кашканов В.А. Аналіз причин виникнення відмов в передній підвісці та рульовому керуванні автомобілів : матеріали XII міжнародної науково-практичної конференції «Сучасні технології та перспективи розвитку автомобільного транспорту», 21-23 жовтня 2019 року / В.А. Кашканов, С.О. Люльчак. - Вінниця : ВНТУ, 2019. - C. 92-94.

\section{References:}

1. «Mobility and transport road safety», An official website of the European Union, [Online], available at: https://ec.europa.eu/transport/road_safety/specialist/statistics_en

2. «Road Safety», National Highway Traffic Safety Administration (NHTSA), [Online], available at: https://www.nhtsa.gov/road-safety

3. Holovan, M.O. (2012), Implementation of the resource and safety of the vehicle at the stages of manufacture, operation and after repair, New technologies, No. 4 (38), pp. 85-92.

4. Kukurudzjak, Yu.Yu. (2016), Monitoring of the technical condition of the car under different operating conditions, Scientific notes, No. 55, pp. 228-231.

5. «The average age of cars in Ukraine is over 20 years», TSN, [Online], available at: https://tsn.ua/ru/ukrayina/sredniy-vozrast-avtomobiley-v-ukraine-prevyshaet-20-let-1146537.html

6. «Resolution adopted by the General Assembly on 25 September 2015», (2015), United Nations. General Assembly URL: https://unctad.org/meetings/en/SessionalDocuments/ares70d1_ru.pdf

7. Mykhajlov, R.I. (2010), «Modern approaches to road safety in Ukraine: ways and experience of improvement», State and regions, No. 2, pp. 156-161. 
8. Evtyukov, S.S. (2020), Metodologiya ocenki i povysheniya effektivnosti dorozhno-transportnyh ekspertiz, D.Sc. Thesis of dissertation, SPbGASU, Saint Petersburg, 355 p.

9. Statistics. Patrol police (2021), [Online], available at: http://patrol.police.gov.ua/statystyka/

10. Dobromirov, V.N. and Evtyukov, S.S. (2013), «Speed as a factor influencing road safety», Modern problems of science and education, No. 5, [Online], available at: https://www.science-education.ru/ru/article/view?id=10248

11. «European Road Safety Status Report "For Safer Roads and Healthier Transport Alternatives"» (2009), World health organization, 161 p., [Online], available at: https://www.euro.who.int/_data/assets/pdf_file/0010/111151/E92789R.pdf?ua=1

12. Lay, M.G. (1992), Ways of the World: A History of the World's Roads and of the Vehicles That Used Them, Rutgers University Press, New Brunswick, $401 \mathrm{p}$.

13. «World report on road traffic injury prevention» (2004), World Health Organization, Geneva, 217 p., [Online], available at: https://apps.who.int/iris/bitstream/handle/10665/42871/9241562609.pdf?sequence=1\&isAllowed=y

14. «The Automobile: A Century of Progress» (1997), Warrendale: Society of Automotive Engineer, 298 p.

15. Khaapaniemi, E.L., Torniainen, Yu., Svatkova. E and Khyuvearinen, Yu. (2008), «Principles and tools for improving road safety on public roads», International experience: Russia-Finland, [Online], available at: https://www.ador.ru/data/files/static/bdd_01.pdf

16. «Tri fakta ob avtoparke Ukrainy v 2019 godu: infografika» (2020), Auto24, [Online], available at: https://auto.24tv.ua/ru/tri_fakta_ob_avtoparke_ukrainy_v_2019_godu_infografika_n19433

17. Podrigalo, M.A. and Abramov, D.V. (2013), «Determination of the limiting dynamic performance of passenger cars», Mehanika ta mashynobuduvannja, naukovo-tehnichnyj zhurnal, NTU «HPI», Harkiv, No. 1, pp. 81-91.

18. Krupchan, V.O. (2020), "Analiz faktoriv, shho vplyvajut' na kerovanist' i stijkist' avtomobilja», materialy mizhnarodnoi' students'koi' konferencii' «Ekspluatacija ta servisna inzhenerija», HNTUSG, Harkiv, pp. 12-13.

19. Vradij, I.O. and Magopec', S.O. (2014), «Doslidzhennja vplyvu zminy geometrychnyh parametriv nesuchoi' systemy legkovogo avtomobilja na pokaznyky povorotnosti i stijkosti», Zbirnyk tez dopovidej VIII Vseukrai'ns'koi' naukovo-praktychnoi' konferencii' studentiv ta aspirantiv "Pidvyshhennja nadijnosti mashyn $i$ obladnannja», KNTU, Kirovograd, Part II, pp. 6-8.

20. Bevz, O.V., Magopec', S.O. and Onopa, V.A. (2010), «Doslidzhennja pracezdatnosti pary tertja «gal'mivnyj dysk gal'mivna kolodka» legkovogo avtomobilja», Zbirnyk naukovyh prac' Kirovograds'kogo nacional'nogo tehnichnogo universytetu. Tehnika $v$ sil's'kogospodars'komu vyrobnyctvi, galuzeve mashynobuduvannja, avtomatyzacija, Issue 23, pp. 23-28.

21. Kashkanov, V.A. and Ljul'chak, S.O. (2019), «Analiz prychyn vynyknennja vidmov v perednij pidvisci ta rul'ovomu keruvanni avtomobiliv», Materialy HII mizhnarodnoi' naukovo-praktychnoi' konferencii" "Suchasni tehnologii' ta perspektyvy rozvytku avtomobil'nogo transportu», 21-23 zhovtnja 2019 roku, VNTU, Vinnycja, pp. 92-94.

Мурашковська Віра Петрівна - старший викладач кафедри автомобільного транспорту та галузевого машинобудування Національного університету «Чернігівська політехніка».

https://orcid.org/0000-0002-0556-8709.

Наукові інтереси:

- методика викладання вищої та прикладної математики на інженерних спеціальностях.

E-mail: vmurashkovska@gmail.com.

Кужельний Ярослав Володимирович - кандидат технічних наук, доцент кафедри автомобільного транспорту та галузевого машинобудування Національного університету «Чернігівська політехніка».

https://orcid.org/0000-0002-5269-8557.

Наукові інтереси:

- процеси механічної обробки.

E-mail: k.y.v.immortal@gmail.com.

Скляр Василь Михайлович - аспірант, асистент кафедри автомобільного транспорту та галузевого машинобудування Національного університету «Чернігівська політехніка».

https://orcid.org/0000-0003-0563-6887.

Наукові інтереси:

- процеси механічної обробки.

E-mail: uslhj@meta.ua.

Слєднікова Олена Сергіївна - кандидат технічних наук, доцент кафедри автомобільного транспорту та галузевого машинобудування Національного університету «Чернігівська політехніка».

https://orcid.org/0000-0002-5444-1747.

Наукові інтереси:

- процеси механічної обробки.

E-mail: sliednikova@gmail.com. 